\title{
Preformation to punctuation
}

\section{Colin Patterson}

Evolution: The History of an Idea. By Peter J. Bowler.

University of California Press: 1984. Pp. 412.

Hbk \$34.45, £23.95; pbk \$12.60, £8.75.

I CAME to this excellent book with vague misgivings, remembering the tedium of Henry Fairfield Osborn's From the Greeks to Darwin, or Edward Clodd's Pioneers of Evolution. No need to worry, for neither is cited in Peter Bowler's massive 54-page bibliography, and history of science is long past relentless progress towards today's truth, as chronicled in those older works. But Bowler does say that

A few years ago, it would have been difficult to write a history of evolutionism except from the perspective that the modern form of Darwinism represents a triumphant climax to the process.

To my real surprise, I learned from Bowler's bibliography that his book has no real competitor - there is no modern, general history of evolutionism. The closest competitors, I suppose, are D.R. Oldroyd's Darwinian Impacts (Open University Press, 1980), and Ernst Mayr's magnum opus, The Growth of Biological Thought (Harvard University Press, 1982). In his opening chapter Bowler notes, and denies, the distinction between "internalist" and "externalist" historians of science, the first studying the "objective process of scientific discovery", the second looking at "how society reacted". He argues that the distinction disappears once we realize that scientific knowledge is not purely objective; perhaps, but one would have to rate Oldroyd's book as more externalist than Bowler's, and Mayr's as more internalist. Both are more difficult going. Bowler aims at readers with no background in either biology or history, especially students in history of science, but I believe that most biologists and many other scientists could read him with pleasure and profit.

The book is finely and carefully balanced, as exemplified by the arrival of On the Origin of Species exactly midway through the text, so that half the book is pre-1859, and half after that date. Bowler has particular strengths in both halves, for he has published in history of biology from seventeenth-century theories of reproduction to twentieth-century genetics, notably in books on nineteenthcentury palaeontology (Fossils and Progress; Science History Publications, 1976) and on "anti-selectionism" around 1900 (The Eclipse of Darwinism; Johns Hopkins University Press, 1983). Throughout the book, I was struck by the way Bowler compresses complicated ideas into a page or two, and still finds space for illuminating comment: someone who can do this even for so thoroughly studied a figure as Darwin (for example on $\mathrm{pp}$. 142-146) is doing excellent work.

There are two technical blemishes, the first trifling, of the kind it pleases pedants to discover - the portrait on the dustjacket, said to be of J.B.S. Haldane, is his father J.S. The second blemish, more intrusive, is Bowler's usage of the word "hierarchy", a vital and recurring concept in the history of evolution. He uses "hierarchy" to mean linear sequence, as in the "chain of being" or a chain of command, where the general's orders pass down the military hierarchy to the private. But in biology today, "hierarchy" entails the inclusion relation, so that the higher includes the lower rather than outranks it: this usage is definitive in taxonomy, but also general in ontogenetic theory and other fields invoking theories or processes of branching. Bowler's idiosyncratic or old-fashioned usage leads to apparently nonsensical statements such as "Linnaeus' system [of classification]... does not imply a hierarchical ranking" or "Cuvier's reluctance to accept hierarchical classification"-here the notion of branching, or inclusion, is seen as the antonym of hierarchy.

The book ends with a chapter on "The
Modern Debates", picking out four or five areas of controversy. Surprisingly neutralism, and the associated "molecular clock", get no mention here. Indeed, neutralism receives very short shrift in the book, three passing mentions, one of which is mistaken:

If the survival of the fittest were necessarily true, it would be impossible for anyone to imagine that it was false-yet there have been theories of evolution based on random factors that deny the superior reproductive power of the fit.

The mistake here is to equate natural selection with change (directional selection), whereas neutralists emphasize the dominance of stabilizing selection, which resists change. Neutral theory seems to me to deserve at least as much space as punctuated equilibrium, which gets a very fair hearing, and modern Creationism, which gets 11 pages. But one point in those pages deserves thought:

It may sound paradoxical, but the only way creationists can be forced to expose their own extraordinary theory to close analysis is if evolutionists concede that they cannot prove their own case. It is only by admitting the lack of certainty inherent in any theory that we can shift the argument to a new level.

Bowler occasionally slips from that noble level, as with "The true story of the horse's evolution has turned out to be rather more complicated" and similar comments implying access to the truth on human evolution. But all in all, I salute what I believe is a superb job.

Colin Patterson is Senior Principal Scientific Officer in the Palaeontology Department, British Museum (Natural History), London.

\section{Records of the early metazoans}

\section{Steven M. Stanley}

The Dawn of Animal Life: A

Biohistorical Study.

By Martin F. Glaessner.

Cambridge University Press: 1984.

Pp. 244. f25, \$49.50.

FOR nearly a century after Darwin published On the Origin of Species, the nature of Precambrian life was debated fruitlessly in a climate of empirical uncertainty. Early fossil finds were continually announced and continually debunked, so that in any given year some claims were alive but clearly vulnerable to rejection.

During the 1950 s and 1960 s, the discovery of four types of Precambrian and earliest Cambrian fossils altered the picture dramatically, adding greatly to the temporal range of palaeontological inquiry. The four new fossil groups were single cells preserved in fine-grained sedimentary rocks; imprints of soft-bodied animals; tiny skeletal fossils slightly older than the first Cambrian trilobites; and trace fossils (tracks, trails and burrows). Of the four, single cells have often been seen as the most exciting finds, partly because their record extends some $2 \times 10^{9}$ years further back in time than the record of multicellular life. In many ways, however, the study of Precambrian cells has been disappointing: increase in cell size and surface complexity about $1.4 \times 10^{9}$ years ago point to the primary expansion of eukaryotes at this time, but the fossil record reveals little about the biological nature of earlier prokaryotic cells. The early metazoan record has been far more revealing, and we must welcome Martin Glaessner's publication of a book that focuses on this record, pulling together our knowledge, while briefly reviewing Precambrian microfossils. Glaessner, a pioneer in the study of Precambrian metazoans, has kept abreast of new developments, including many in the Soviet Union that have gone largely unnoticed elsewhere.

As might be expected, Glaessner devotes about half of his book to the spectacular 